\title{
The Role of the Researcher When Using the Socio-Anthropological Method to Understand the Phenomenon of Alcoholism
}

\author{
Elizabeth Halpern, Ligia Costa Leite \\ Institute of Psychiatry, Federal University of Rio de Janeiro, Rio de Janeiro, Brazil \\ Email: espindolahalpern@yahoo.com.br
}

Received 6 April 2015; accepted 5 May 2015; published 8 May 2015

Copyright (C) 2015 by authors and Scientific Research Publishing Inc.

This work is licensed under the Creative Commons Attribution International License (CC BY). http://creativecommons.org/licenses/by/4.0/

(c) (i) Open Access

\section{Abstract}

The consumption of alcoholic beverages during the Brazilian Armed Forces working hours was studied for the first time only recently, by investigating the patients of the Center for Chemical Dependency (CEDEQ) of the Brazilian Navy. This was possible mainly because one of the researchers was the chief of this clinic and one of the psychologists of the therapeutic groups. This article discussed methodological aspects related to the role of the researcher when conducting a qualitative research through a dense ethnography in CEDEQ over four years, with participant observation in two treatment groups for 24 sessions. Additionally, a multiple case and explanatory study was carried on, through individual and 13 open-ended interviews. The following findings will be discussed: 1) the social construction of truth and accuracy of the oral statements; 2) reflexivity, transparency, and familiarity of the researcher with the field; 3 ) impression management, standardized behavior, and resistance to perform the research. The use of the qualitative method requires the assessment of the researcher's role. The anthropological eye helped to deal with a delicate theme that was hard to access: drinking during the military working journey. We found out that the organization had an ambivalent position: though the Brazilian Navy created this specialized clinic and allowed this research, at the same time this organization was not open to discuss inebriation on board, strictly authorizing the investigation of the patients. This was possible mainly because of the researcher's social and hierarchical position as an officer, as the chief of the CEDEQ, and for being one of the therapists of the groups. We concluded that this position created an obstacle to apply effective measures to protect the military contingency.

\section{Keywords}

Qualitative Research, Ethnography, Participant Observation, Military Personnel, Researcher-Subject Relations, Alcoholism 


\section{Introduction}

The consumption of alcoholic beverages during the Brazilian Armed Forces working hours was studied for the first time only recently. The results of the study undertaken in an outpatient clinic for the treatment of chemical dependency of the Brazilian Navy represented a pioneer initiative. In fact, the naval organization is not available to be investigated, especially if the subject concerns one of its main traditions: drinking on board. Consequently, the best strategy to learn a little about it was to investigate the patients of the Center for Chemical Dependency (CEDEQ) of the Brazilian Navy. This was possible mainly because one of the researchers was the Chief of this clinic and one of the psychologists of the therapeutic groups.

The main objective of the research was to examine the role of the Brazilian Navy work environment in determining the alcoholism of the CEDEQ's patients. In this manuscript we would not present the findings obtained from the ethnography in the CEDEQ and in the therapeutic groups, neither those derived from the interviews with the patients, because these findings were presented in other opportunities [1]-[19].

This article discusses important methodological aspects that are present throughout this investigation, related to the role of the author as a researcher.

\section{Method}

\section{Field of Study}

The CEDEQ, an outpatient clinic specialized in chemical dependency, unparalleled in the Brazilian Armed Forces, offers a treatment based on group therapy, carried out by psychologists and psychiatrists. Although it is open to all servicemen, the enlisted personnel comprise almost a hundred percent of the patients, while officers rarely seek help on CEDEQ, requiring private sessions instead.

A qualitative research was conducted through a dense ethnography [20] [21] in the CEDEQ over four years, with participant observation [22]-[24] in two treatment groups for 24 sessions. Additionally, a multiple case and explanatory study was carried out, through individual and semi-structured (open-ended) interviews [25], which were recorded and transcribed. Thus, 13 individuals randomly selected from 25 patients could tell their stories in their own way [26], following the relevance of their memories.

\section{Results and Discussion}

The following findings, that will be presented, are related to the role of the author as a researcher. Although they were not foreseen in the research objectives, because of their relevance, they will be discussed next: 1) the social construction of truth and accuracy of the oral statements; 2) reflexivity, transparency, and familiarity of the researcher with the field; 3) impression management, standardized behavior, and resistance to perform the research.

\subsection{The Social Construction of Truth and Accuracy of the Oral Statements}

Through ethnography, participant observation, and interviews with CEDEQ's patients, we could perceive that their experience of alcoholism was determined by the intersection among organic, psychological, cultural, and social aspects. The interpretative understanding of the narratives helped identify certain angles of cultural reality [27], aware that their points of view do not necessarily reflect the "truth" of these patients' representations of their alcoholism. Their conceptions concerning their "illness" are seen as partial, crossed by streams of cultural traditions. Actually, "reality” comes from a cultural construction; it does not arise from a single source, because it depends on personal perspectives and experiences [28]. In addition, based on constructivist perspective, the interviewer and the interviewees are involved in the construction of meanings [26] [29] [30] on their representations of "illness" and "cure" that varies according to each individual [1]-[7].

Oral statements are usually seen as inaccurate and unrealistic. The interviewer should not focus on capturing the "truths" of respondents, nor trace the genealogy of the facts in order to corroborate or refute data [31]. Therefore, the narratives relied on their invaluable personal experiences. Besides, studies have pointed that the increased familiarity of the researcher with the field of study enhances the chances that individuals present more reliable answers [30] [32].

The narrative is a symbolic practice permanently open to reformulation, which is anchored both in memory and oblivion [33]. The story told by the patients did not follow a chronology, or depended on the mnemonic 
ability to recover "accurate" information about the history of the "disease", since it is not waiting to be discovered. In accordance to this perspective, alcoholism would be a socially constructed phenomenon [34].

\subsection{Reflexivity, Transparency, and Familiarity of the Researcher with the Field}

The use of the ethnographic method helped to understand their point of views [35]; and the use of the critical ethnography [36] [37] allowed the inspection of their behavior in the organization, examining the historical, social, cultural, and political aspects [25]. Thus, a reflective learning was ensured, based on interactional perspective [38]. In fact, individuals are seen as a product of social interaction [39] [40], highlighting the social and discursive conjunctures in which emerge the multiple subjective experiences of illness, and enabling the understanding of their meanings.

Considering that the results of a qualitative study depend on the transparency with which the search process is described, another key methodological aspect refers to the importance of the interaction between the interviewer and the interviewees. The matter of reflexivity refers to the awareness of the researcher about the influence of certain elements in the interaction with the interviewees. At this stage, the details of the context, as well as the personal characteristics of the patients and the researcher are relevant, such as gender, ethnicity, and social class [41]. The interpretation of the researcher was influenced by her own concepts, though open to criticism and reinterpretation [21]. The researcher's prejudices must be observed to avoid biases that could interfere with the results. A certain degree of contamination is expected since there is no absolute neutrality [42]. In fact, even the choice of the problem to be studied originated from her sociocultural universe.

Although neutrality may be seen as an illusion [43] [44], her role should be clearly stated and discussed; it should not be taken for granted. In effect, the first author could be considered as "native", since she works in the field of work. On one hand this enabled her to develop a deeper look, from an angle that a non-native researcher would hardly have access. She had the benefit of being immersed in this universe, making observations over a long period [20]. Consequently, she was able to perceive important issues power relations in the sphere of work.

The proximity of the researcher with the object of the study was a crucial matter of investigation. Because of the researcher's familiarity with the field, she could be considered as "native". At first, she believed that the lack of neutrality could disqualify the research. Nevertheless, according to the socio-anthropological eye she understood that a researcher does not have to be "totally neutral" to understand what is going on in a specific area of study. Still, this became a paramount concern of this research, mainly to be aware of the effects of belonging to the field [14].

On the other hand, her hierarchical position before the patients sometimes aroused uncertainties about her objectives. However, her previous acquaintance with patients as Chief of CEDEQ and therapist of the groups helped to reduce skepticism and to establish a positive rapport. Suspicions may be due to the existence of a latent distrust among enlisted personnel about the intentions and attitudes of officers. Historically, a gap between these two segments can be noticed, affected by domain and subjugation episodes, including the use of the whip until the first decades of the twentieth century [1] [13].

The illusion of transparency [23] [45] is one of the biggest challenges of the investigator. In our case, although the first author felt familiar with her field of study, she recognized that such familiarity was apparent, requiring a permanent critical awareness [46]. Thus, she had to deal with the challenge of proximity [47] [48]. Undoubtedly, the dual status of the author, personal and professional, required a constant ethnographic state, that is, a permanent observation [49].

\subsection{Impression Management, Standardized Behavior, and Resistance to Perform the Research}

During the investigation, a social interaction occurred, elicited by the author and the patients along the interviews and field observations. It involved the control and interpretation of impressions-impression management, due to a certain level of dissimulation in any relationship. Therefore, the researcher played a standardized behavior [50] before the patients, keeping her beliefs and opinions to herself. Indeed, the social-anthropological method accepts this kind of interference, recognizing that it is intrinsic to the research. The researcher had to be aware that both sides always modulate their roles, consciously or not, following the rules of politeness and decorum, by selecting what they want to exhibit or conceal from each other.

For being a member of the Brazilian Navy, the first author had some degree of autonomy to develop the in- 
vestigation. She had, full access to the field of study, since she was officially authorized by her hierarchical superiors to conduct the research. Although she had to fulfill all the bureaucratic and academic requirements to develop studies in this clinic, still she had to overcome the institutional resistance for carrying out studies on the tradition of drinking on board. Addition she had to face the discomfort caused in her workplace for being at the university, away from the daily tasks. In fact, the existence of certain barriers to investigate Brazilian military institutions were mentioned by other authors before [51] [52], which appear to be stressed before the issue concerning the tradition of drinking during the work journey and alcoholism among military personnel [1]-[19].

The chances of a civilian researcher obtain permission to conduct investigations in the Brazilian Armed Forces are remote, mainly because these organizations have never been an object of study previously. If that occurred, we believe that a significant number of masks would emerge between the investigator and the naval institution, concealing or revealing information, by selecting the most "appropriate" one. The presence of an external investigator could enhance concealment among the parties involved. As a result, there would be an effort to display the most charming and popular facets of the organization, for instance: the good manners, the neatness of the uniforms, and the cleaning of military facilities. Despite the friendly receptivity, this would not guarantee the researcher's entrance to the most secret areas of the institution, though the vital zones will remain veiled [50].

Nevertheless, based on the results, we observed that some patients took advantage of this exceptional opportunity of being informants to reveal their opinions about the institution. By assuming this privileged position, uncensored, they could momentarily be divested of their devalued status, free to tell a little about what goes on behind the scenes of the naval organization, because they have little to lose.

In fact, many enlisted personnel may be a burden to the organization, just like the CEDEQ's patients. In general, the impact of their testimonies tend to be neutralized because they are not considered relevant or true, mainly because they tend to be undervalued [1] [16]-[19].

\section{Conclusions}

Although the Brazilian Navy provides specialized treatment for drug addicts, the institution is more concerned with those who are already affected by the heavy alcohol consumption, because their flaws are visible, like: absenteeism, low productivity in the workplace, family and financial problems, aggressiveness, and disciplinary misdemeanors.

Those who drink "socially" and that do not exhibit visible failures related to alcohol consumption need the proper assistance as well. According to the patients, these drinkers should be helped earlier to avoid the harmful effects of intoxication. In general, when a military is referred to this Center, this substance has already damaged his/her personal and professional lives.

The anthropological eye helped to deal with a delicate theme that was hard to access. In fact, the organization has an ambivalent position. Though the Brazilian Navy created this specialized clinic and allowed this research, at the same time this organization was not open to discuss inebriation on board, strictly authorizing the investigation of the patients, due to the researcher's social and hierarchical position as an officer, the chief of the CEDEQ, and one of the therapists of the groups.

Finally, this institution seems unaware of what is going on in its core. Meanwhile, it keeps on stimulating alcohol consumption and creating opportunities to feast. As a result, we concluded that it was a challenge to apply effective measures to protect the military contingency.

\section{References}

[1] Halpern, E.E. (2013) The "Uniform” and the "Cup”: The Constitution of the Alcoholic Habitus in the Brazilian Navy. Thesis (Doctoral in Mental Health), Federal University of Rio de Janeiro, Institute of Psychiatry, Rio de Janeiro.

[2] Halpern, E.E., Ferreira, S.M.B. and da Silva Filho, J.F. (2008) The Effects of the Labor Situations in the Construction of the Alcoholism of the Brazilian’s Navy Military Patients. Cadernos de Psicologia Social e do Trabalho, 11, 273-286. http://dx.doi.org/10.11606/issn.1981-0490.v11i2p273-286

[3] Halpern, E.E., Leite, L.M.C. and da Silva Filho, J.F. (2010) Drinking on Board: Learned Tradition. Antropolítica: Revista Contemporânea de Antropologia e Ciência Política, 28, 151-176.

[4] Halpern, E.E. and Leite, L.M.C. (2010) The Dry Law on Board: Preventive Challenges in Brazilian Navy. Arquivos Brasileiros de Psicologia, 62, 103-114. 
[5] Halpern, E.E. and Leite, L.M.C. (2011) The Construction of the Alcoholic Habitus and Alcohol Consumption in the Workplace among Military Patients of Brazilian Navy. Cadernos de Saúde Coletiva, 19, 356-365.

[6] Halpern, E.E. and Leite, L.M.C. (2011) Deciphering the Meanings of Navy Ethylic Behaviors of Military Patients. Boletim de Psicologia, 61, 177-191.

[7] Halpern, E.E. and Leite, L.M.C. (2012) Representations on Patient Illness and Cure at the Chemical Dependency Center of the Central Navy Hospital. Ciência e Saúde Coletiva, 17, 1079-1089. http://dx.doi.org/10.1590/S1413-81232012000400029

[8] Halpern, E.E. and Leite, L.M.C. (2012) The "Cooked Crab” Uniform and the "Branquinha”: Life Narratives of a Military Alcoholic Patient. Cadernos de Psicologia Social e do Trabalho, 15, 65-80. http://dx.doi.org/10.11606/issn.1981-0490.v15i1p65-80

[9] Halpern, E.E. and Leite, L.M.C. (2013) The Connection between Sailors’ Duties and Alcoholism. Revista Psicologia: Organizações e Trabalho, 13, 111-126.

[10] Halpern, E.E. and Leite, L.M.C. (2013) Opportunities to Drink on Board: Characteristics of Naval Labor. Physis, 23, 1277-1296. http://dx.doi.org/10.1590/S0103-73312013000400013

[11] Halpern, E.E. and Leite, L.C. (2014) Alcoholism in the Working Day: Peculiarities of Naval Life. Saúde e Sociedade, 23, 131-145. http://dx.doi.org/10.1590/S0104-12902014000100010

[12] Halpern, E.E. and Leite, L.C. (2014) Examining the Role of Brazilian Navy before Alcohol Intake in the Workplace. Psychology, 5, 104-108. http://dx.doi.org/10.4236/psych.2014.52016

[13] Halpern, E.E. and Leite, L.C. (2014) Brazilian Navy: A Trajectory of Uniform(ization). Antíteses, 7, 158-183. http://dx.doi.org/10.5433/1984-3356.2014v7n13p158

[14] Halpern, E.E. and Leite, L.C. (2014) The Alcoholic Habitus: A Socio-Anthropological Eye on Alcoholism. Journal of Addiction Research and Therapy, 5, 190. http://dx.doi.org/10.4172/2155-6105.1000190

[15] Halpern, E.E. and Leite, L.C. (2014) The “Uniform” and the “Cup”: (Un)necessary Crossovers. Antropolítica: Revista Contemporânea de Antropologia e Ciência Política, 36, 179-209.

[16] Halpern, E.E. and Leite, L.C. (2014) “Drunkard”, “Juicer”, “Hammered”: Sociodynamics of Stigmatization in the Naval Work. Revista de Ciências Humanas, 48, 329-351. http://dx.doi.org/10.5007/2178-4582.2014v48n2p329

[17] Halpern, E.E. and Leite, L.C. (2015) Availability of Alcoholic Beverages during the Brazilian Navy Working Hours. SAGE Open, 5, 1-12. http://dx.doi.org/10.1177/2158244015574626

[18] Halpern, E.E. and Leite, L.C. (2015) The Dual Commitment of a Naval Outpatient Clinic Specialized in Chemical Dependency of the Brazilian Navy: With Patients and the Institution. Ciência e Saúde Coletiva. In Press.

[19] Halpern, E.E. and Leite, L.C. (2015) Traditions and Punishments: The White Rum of the Sailor and the Whisky of the Commander Dilemas. In Press.

[20] Hughes, E.C. (1960) Introduction: The Place of Field Work in Social Science. In: Junker, B.H., Ed., Field Work: An Introduction to Social Sciences (X-XV), University of Chicago Press, Chicago.

[21] Geertz, C. (1973) The Interpretation of Cultures. Basic Books, Inc., New York.

[22] Malinowsky, B. (1922/1984) Argonauts of the Western Pacific: An Account of Native Enterprise and Adventure in the Archipelagoes of Melanesian New Guinea. George Routledge \& Sons, Ltd., London, E. P. Dutton \& Co., New York.

[23] Minayo, M.C.S. (2006) The Challenge of Knowledge: Qualitative Research in Health. Hucitec, São Paulo.

[24] Minayo, M.C.S., Deslandes, S.F. and Gomes, R. (2007) Social Research: Theory, Method and Creativity. Vozes, Petrópolis.

[25] Fossey, E., Harvey, C., McDermott, F. and Davidson, L. (2002) Understanding and Evaluating Qualitative Research. Australian \& New Zealand Journal of Psychiatry, 36, 717-732. http://dx.doi.org/10.1046/j.1440-1614.2002.01100.x

[26] Groleau, D., Young, A. and Kirmayer, L. (2006) The McGill Illness Narrative Interview (MINI): An Interview Schedule to Elicit Meanings and Modes of Reasoning Related to Illness Experience. Transcultural Psychiatry, 43, 671-691. http://dx.doi.org/10.1177/1363461506070796

[27] Weber, M. (2003) The “Objectivity” of Knowledge in Social Sciences. In: Cohn, G., Ed., Max Weber: Sociology, Ática, Rio de Janeiro, 79-127.

[28] Barth, F. (1989) The Analysis of Culture in Complex Societies. Ethnos, 54, 120-142. http://dx.doi.org/10.1080/00141844.1989.9981389

[29] Holstein, J.A. and Gubrium, J.F. (1995) The Active Interview. SAGE, Thousand Oaks. http://dx.doi.org/10.4135/9781412986120

[30] Whitley, R. and Crawford, M. (2005) Qualitative Research in Psychiatry. Canadian Journal of Psychiatry, 50, 108114. 
[31] Thompson, P. (2000) The Voice of the Past: Oral History. Oxford University Press, Oxford.

[32] Denzin, N.K. and Lincoln, Y.S. (2005) The SAGE Handbook of Qualitative Research. Sage, Thousand Oaks.

[33] Lambek, M. (1996) The Past Imperfect: Remembering as Moral Practice. In: Antze, P. and Lambek, M., Eds., Tense Past: Cultural Essays in Trauma and Memory, Routledge, London, 235-254.

[34] Fainzang, S. (1996) Ethnologie des anciens alcooliques: La liberté ou la mort. Presses Universitaires de France, Paris.

[35] Spradley, J. (1979) The Ethnographic Interview. Harcourt Brace, Fort Worth.

[36] Schwandt, T. (1997) Qualitative Inquiry: A Dictionary of Terms. Sage, Thousand Oaks.

[37] Cook, K.E. (2005) Using Critical Ethnography to Explore Issues in Health Promotion. Qualitative Health Research, 15, 129-138. http://dx.doi.org/10.1177/1049732304267751

[38] Whyte, W.F. (1943/2005) Street Corner Society: The Social Structure of an Italian Slum. University of Chicago Press, Chicago.

[39] Mead, G.H. (1982) The Individual and the Social Self: Unpublished Essays by G. H. Mead. In: Miller, D.L., Ed., University of Chicago Press, Chicago.

[40] Blumer, B. (1986) Symbolic Interaction: Perspective and Method. University of California Press, California.

[41] Richards, H. and Emslie, C. (2000) The “Doctor” or the "Girl from the University”? Considering the Influence of Professional Roles on Qualitative Interviewing. Family Practice, 17, 71-75. http://dx.doi.org/10.1093/fampra/17.1.71

[42] Malterud, K. (2001) Qualitative Research: Standards, Challenges, and Guidelines. Lancet, 358, 483-488. http://dx.doi.org/10.1016/S0140-6736(01)05627-6

[43] Becker, H.S. (1977) De que lado estamos? Uma teoria da ação coletiva. Zahar Editores, Rio de Janeiro.

[44] Martins, H.H.T.deS. (2004) Qualitative Research Methodology. Education and Research, 30, 289-300.

[45] Bourdieu, P. (1983) Trabalhos e projetos. In: Ortiz, R., Org., Pierre Bourdieu: Sociologia, Ática, São Paulo.

[46] Bourdieu, P. (2005) Esboço de auto-análise. Companhia das Letras, São Paulo.

[47] Velho, G. (1978) Observando o familiar. In: Nunes, E.deO., Org., A aventura sociológica, Zahar Editores, Rio de Janeiro, 36-46.

[48] Velho, G. (1998) Nobres \& anjos: Um estudo de tóxicos e hierarquia. FGV, Rio de Janeiro.

[49] Duarte, L.F.D. and Gomes, E.deC. (2008) Three Families: Identities and Transgenerational Trajectories in the Lower Classes. FGV, Rio de Janeiro.

[50] Berreman, G. (1962/1980) Behind Many Masks. In: Zaluar, A., Ed., Unveiling Social Mask, Livraria Francisco Alves, Rio de Janeiro, 123-174.

[51] Coelho, E.C. (1976) Em busca de identidade: O Exército e a política na sociedade brasileira. Forense Universitária, Rio de Janeiro.

[52] Castro, C. (2004) The Military Spirit: An Anthropologist in the Barracks. Zahar Ed., Rio de Janeiro. 